\title{
Quantal ATP release in rat $\beta$-cells by exocytosis of insulin-containing LDCVs
}

\author{
Jovita Karanauskaite $\cdot$ Michael B. Hoppa • \\ Matthias Braun • Juris Galvanovskis • Patrik Rorsman
}

Received: 8 August 2008 / Accepted: 25 October 2008 / Published online: 19 November 2008

(C) Springer-Verlag 2008

\begin{abstract}
Quantal release of adenosine triphosphate (ATP) was monitored in rat pancreatic $\beta$-cells expressing $\mathrm{P} 2 \mathrm{X}_{2}$ receptors. Stimulation of exocytosis evoked rapidly activating and deactivating ATP-dependent transient inward currents (TICs). The unitary charge $(q)$ of the events recorded at $0.2 \mu \mathrm{M}\left[\mathrm{Ca}^{2+}\right]_{\mathrm{i}}$ averaged $4.3 \mathrm{pC}$. The distribution of the ${ }^{3} \sqrt{q}$ of these events could be described by a single Gaussian. The rise times averaged $\sim 5 \mathrm{~ms}$ over a wide range of TIC amplitudes. In $\beta$-cells preloaded with 5 hydroxytryptamine (5-HT; accumulating in insulin granules), ATP was coreleased with 5 -HT during $>90 \%$ of the release events. Following step elevation of $\left[\mathrm{Ca}^{2+}\right]_{i}$ to $\sim 5 \mu \mathrm{M}$ by photo release of caged $\mathrm{Ca}^{2+}$, an increase in membrane capacitance was observed after $33 \mathrm{~ms}$, whereas ATP release first became detectable after $43 \mathrm{~ms}$. The step increase in $\left[\mathrm{Ca}^{2+}\right]_{\mathrm{i}}$ produced an initial large TIC followed by a series of smaller events that echoed the changes in membrane capacitance $\left(\Delta C_{\mathrm{m}}\right)$. Mathematical modeling suggests that the large initial TIC reflects the superimposition of many unitary events. Exocytosis, measured as $\Delta C_{\mathrm{m}}$ or TICs, was complete within $2 \mathrm{~s}$ after elevation of $\left[\mathrm{Ca}^{2+}\right]_{\mathrm{i}}$ with no sign of endocytosis masking the capacitance increase. The relationship between total charge $(Q)$ and $\Delta C_{\mathrm{m}}$ was linear with a slope of $\sim 1.2 \mathrm{pC} / \mathrm{fF}$. The latter value predicts a capacitance increase of $3.6 \mathrm{fF}$ for the observed mean value of $q$, close to that expected for exocytosis of individual insulin granules. Our results indicate that measurements of ATP release and $\Delta C_{\mathrm{m}}$ principally $(\geq 85-$ $95 \%)$ report exocytosis of insulin granules.
\end{abstract}

J. Karanauskaite · M. B. Hoppa · M. Braun · J. Galvanovskis • P. Rorsman $(\bowtie)$

OCDEM, University of Oxford, Churchill Hospital,

Oxford OX3 7LJ, UK

e-mail: patrik.rorsman@drl.ox.ac.uk
Keywords 5-Hydroxytryptamine $\cdot$ Membrane capacitance . Exocytosis · Calcium entry · Cyclic AMP - Diabetes . Insulin secretion · Pancreatic $\beta$-cell · ATP ATP release . Insulin · Exocytosis · LDCV · ATP

\section{Introduction}

Capacitance measurements and amperometry are widely used to study single-vesicle release from endocrine cells [1, 2]. Secretory cells contain both large dense core vesicles (LDCVs) and small synaptic-like microvesicles (SVs) [3]. Whole-cell capacitance measurements monitor the increase in cell surface area that occurs when the vesicular membranes are inserted into the plasma membrane. However, it is not possible to discriminate between exocytosis of SVs and LDCVs and their relative contributions to the observed changes in membrane capacitance remain unknown.

Pancreatic $\beta$-cells are electrically excitable and changes in blood glucose translate into changes of insulin secretion via electrical activity [4]. In addition to insulin-containing LDCVs, they also contain SVs $[5,6]$ capable of undergoing exocytosis [7]. It has been reported that there is a temporal dissociation between the increase in membrane capacitance and the detection of extracellular serotonin (5hydroxytryptamine, 5-HT), which is coreleased with insulin from $\beta$-cells preloaded with the amine [8-10]. Thus, some (but not all $[10,11]$ ) studies report an early component of capacitance increase that occurs without any detectable release of serotonin. A dissociation between capacitance measurements and LDCV exocytosis studied by amperometry [12] and TIRF imaging of cargo release [13] has also been observed in chromaffin cells. Clearly, these discrepant observations have great impact on the interpretation and 
validity of data obtained by capacitance measurements and merit further analyses.

The insulin granules constitute an important intracellular adenosine triphosphate (ATP) depot [14-16]. Synaptic vesicles also contain ATP [17] but whether this also applies to the SVs in $\beta$-cells is not known. We have engineered primary rat $\beta$ cells to express purinergic ionotropic $\mathrm{P} 2 \mathrm{X}_{2}$ receptors $\left(\mathrm{P} 2 \mathrm{X}_{2} \mathrm{R}\right)$. These ligand-gated channels are activated by extracellular ATP [18]. Exocytosis of ATP-containing secretory vesicles can therefore be expected to transiently elevate extracellular ATP sufficiently to activate the $\mathrm{P} 2 \mathrm{X}_{2} \mathrm{Rs}$ in $\beta$ cells expressing these receptors. Indeed, stimulation of exocytosis in $\beta$-cells expressing $\mathrm{P} 2 \mathrm{X}_{2} \mathrm{Rs}$ is associated with large current transients [19, 20]. We have previously demonstrated that ATP is coreleased with 5-HT [21], consistent with the idea that ATP is released during exocytosis of the LDCVs. However, it remains to be determined whether ATP is also released by exocytosis of the SVs and, if this is the case, how much of the observed capacitance increase reflects fusion of such vesicles with the membrane.

Here, we confirm that ATP is coreleased with the insulin granule marker 5-HT preloaded into pancreatic $\beta$-cells. We further demonstrate that the amplitude distribution of the ATP-induced current transients and kinetics of these events are consistent with the release of a single class of vesicles. Finally, we show that ATP and serotonin are released in parallel with exocytosis detected as increases in membrane capacitance and that there is no temporal dissociation between the processes. We conclude that capacitance increases in rat $\beta$-cells upon stimulation of exocytosis principally reflect exocytosis of insulin-containing LDCVs.

\section{Results}

\section{$\mathrm{P} 2 \mathrm{X}_{2} \mathrm{R}$-based detection of extracellular ATP}

Rat pancreatic $\beta$-cells were infected with ionotropic $\mathrm{P} 2 \mathrm{X}_{2}$ Rs. Secretory vesicles in a variety of secretory cells including $\beta$-cells contain ATP $[15,16,22]$. Exocytosis of insulin granules will therefore be associated with the corelease of ATP $[7,23]$ and result in transient inward currents (TICs). Importantly, exocytotic ATP release will activate $\mathrm{P} 2 \mathrm{X}_{2} \mathrm{Rs}$ and give rise to TICs regardless of the location of the release events (Fig. 1a). By contrast, measurements of exocytosis by amperometry only detect events that occur close to the carbon fiber [21].

In successfully infected $\beta$-cells (as judged by green fluorescent protein (GFP) fluorescence) held at $-70 \mathrm{mV}$, application of $100 \mu \mathrm{M}$ ATP elicited an inward current with a peak amplitude $(I)$ averaging $5.1 \pm 0.5 \mathrm{nA}(n=19$; Fig. $1 \mathrm{~b}$; trace ii); no ATP-activated currents were observed in noninfected $\beta$-cells ( $n=17$; Fig. $1 \mathrm{~b}$, trace i). The spontane- ous decline in the amplitude during the application is due to slow $(\tau>5 \mathrm{~s})$ desensitization of the receptors. At $-70 \mathrm{mV}$, the $\mathrm{P} 2 \mathrm{X}_{2} \mathrm{R}$ single-channel amplitude $(i)$ is $\sim 1 \mathrm{pA}[24]$. The open probability $\left(P_{\mathrm{o}}\right)$ of the channel at a maximally activating concentration of ATP has been reported to be $\sim 0.6$ [25]. The number of receptors per cell $(N)$ can be estimated from the relationship $N=I /\left(i \times P_{o}\right)$. Using the above values of $I, P_{o}$, and $i, N$ can thus be estimated to be $\sim 8,500$. The cell capacitance averaged $10.6 \pm 1.0 \mathrm{pF} \quad(n=19)$. Since

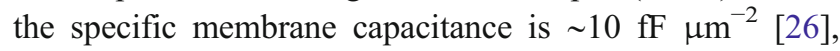
the above value of $N$ corresponds to a receptor density of $80 \mu^{-2}$. This predicts an average distance between two adjacent receptors of $0.11 \mu \mathrm{m}$.

Exocytosis detected by the $\mathrm{P} 2 \mathrm{X}_{2} \mathrm{R}$-based assay

Figure 1c shows recordings of ATP-induced TICs when exocytosis was stimulated by intracellular dialysis with a buffer containing $0.2 \mu \mathrm{M} \mathrm{Ca}^{2+}(\mathrm{i})$ and $2 \mu \mathrm{M} \mathrm{Ca}^{2+}$ in the absence (ii) and presence (iii) of $0.1 \mathrm{mM}$ cyclic adenosine monophosphate (cAMP). These events were suppressed by suramin $(50 \mu \mathrm{M})$, confirming that they are due to activation of $\mathrm{P} 2 \mathrm{X}_{2} \mathrm{Rs}$ (not shown). The $\mathrm{P} 2 \mathrm{X}_{2} \mathrm{Rs}$ respond principally to extracellular ATP and to a much lesser extent to adenosine monophosphate [27]. The frequency of the TICs averaged $9 \pm 1 \mathrm{~min}^{-1}(n=8)$ at $0.2 \mu \mathrm{M}\left[\mathrm{Ca}^{2+}\right]_{\mathrm{i}}, 37 \pm 4 \mathrm{~min}^{-1}$ at $2 \mu \mathrm{M}$ $\left[\mathrm{Ca}^{2+}\right]_{\mathrm{i}}$ alone $\left(n=7 ; P<0.001\right.$ vs. the lower $\mathrm{Ca}^{2+}$ concentration) and $69 \pm 8 \mathrm{~min}^{-1}$ at the higher $\left[\mathrm{Ca}^{2+}\right]_{\mathrm{i}}$ and in the presence of $100 \mu \mathrm{M}$ cAMP ( $n=6: P<0.001$ vs. $2 \mu \mathrm{M} \mathrm{Ca}^{2+}$ alone).

Figure 1d shows the cumulative charge $(\Sigma Q)$ displayed against time after establishment of the whole-cell configuration. Increasing $\left[\mathrm{Ca}^{2+}\right]_{\mathrm{i}}$ from 0.2 to $2 \mu \mathrm{M}$ stimulated exocytosis approximately fourfold (from 185 to $700 \mathrm{pC}$ ). The inclusion of $100 \mu \mathrm{M}$ cAMP in the intracellular medium resulted in a further sixfold enhancement of exocytosis. The average unitary event size $(q)$ was estimated by dividing $\Sigma Q$ by the observed number of events. It averaged $4.3 \pm 0.4 \mathrm{pC}$ $(n=8)$ and $5.3 \pm 0.6(n=8)$ at $0.2 \mu \mathrm{M}\left[\mathrm{Ca}^{2+}\right]_{\mathrm{i}}$ in the absence and presence of $100 \mu \mathrm{M}$ cAMP, respectively. At the tenfold higher $\left[\mathrm{Ca}^{2+}\right]_{\mathrm{i}}, q$ averaged $6.6 \pm 0.5 \mathrm{pC}(n=5 ; P<0.05$ vs. $\left.0.2 \mu \mathrm{M}\left[\mathrm{Ca}^{2+}\right]_{\mathrm{i}}\right)$ under control conditions and $19.2 \pm 4.2 \mathrm{pC}$ $(n=5)$ in the presence of $100 \mu \mathrm{M}$ intracellular cAMP $(P<0.05$ vs. $2 \mu \mathrm{M}\left[\mathrm{Ca}^{2+}\right]_{\mathrm{i}}$ alone). The latter effect is reminiscent of the approximately fivefold increase in the amplitude and charge of the exocytotic events previously documented by amperometry in mouse $\beta$-cells following elevation of intracellular cAMP levels by activation of adenylate cyclase by forskolin [9].

Properties of quantal ATP release in $\beta$-cells

At $0.2 \mu \mathrm{M}\left[\mathrm{Ca}^{2+}\right]_{\mathrm{i}}$, the frequency of the TICs is low enough to allow the resolution of the individual events. Figure $2 \mathrm{a}$ shows the distribution of the ${ }^{3} \sqrt{q}$ values. It can be described 
a

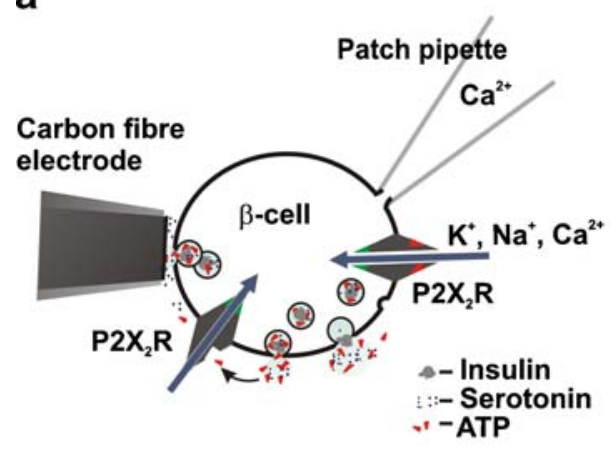

C

i)

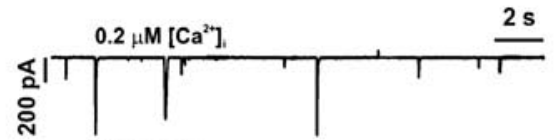

ii)

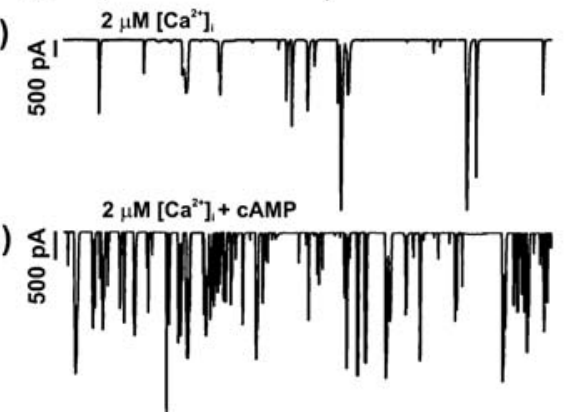

b

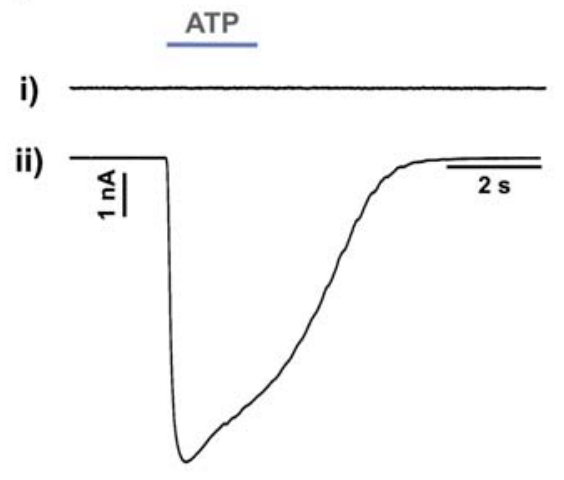

d

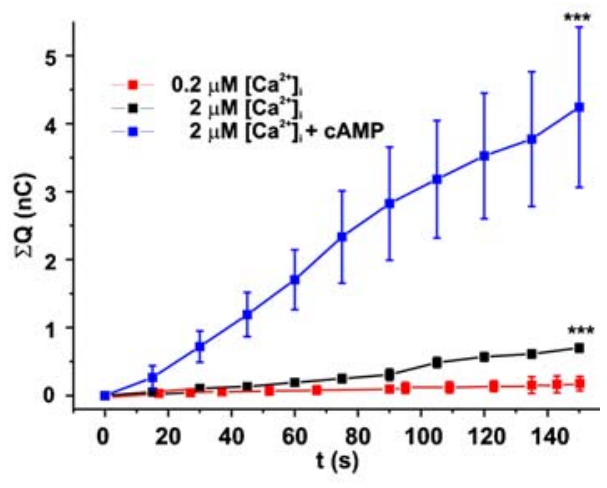

$\mathrm{P} 2 \mathrm{X}_{2}$ receptor-GFP $\left(\mathrm{P} 2 \mathrm{X}_{2} \mathrm{R}\right.$-GFP; ii). c TICs observed in a $\beta$-cell dialyzed with intracellular buffer containing $0.2 \mu \mathrm{M}\left[\mathrm{Ca}^{2+}\right]_{\mathrm{i}}(i), 2 \mu \mathrm{M}$ $\left[\mathrm{Ca}^{2+}\right]_{\mathrm{i}}(i i)$, and $2 \mu \mathrm{M}\left[\mathrm{Ca}^{2+}\right]_{\mathrm{i}}+100 \mu \mathrm{M}$ cAMP (iii). d Time-dependent increase in cumulative charge $(\Sigma \mathrm{Q})$ measured in cells dialyzed with $0.2 \mu \mathrm{M}\left[\mathrm{Ca}^{2+}\right]_{\mathrm{i}}(\mathrm{red} ; n=8), 2 \mu \mathrm{M}\left[\mathrm{Ca}^{2+}\right]_{\mathrm{i}}($ black; $n=5)$, and $2 \mu \mathrm{M}$ $\left[\mathrm{Ca}^{2+}\right]_{\mathrm{i}}+100 \mu \mathrm{M}$ cAMP $(n=5) .{ }^{* * *} P<0.001$ for the differences between the total increase in $\mathrm{Q}$ over $150 \mathrm{~s}$ between the low and high $\left[\mathrm{Ca}^{2+}\right]_{i}$ and absence and presence of cAMP at the higher $\left[\mathrm{Ca}^{2+}\right]_{i}$

Parallel release of ATP and 5-HT

Exocytosis of insulin-containing LDCVs can be studied by amperometry following preloading of the $\beta$-cell and the LDCVs with 5-HT [8]. Figure 3a shows parallel recordings of ATP (black trace) and 5-HT release (red trace). Exocytosis was elicited by intracellular dialysis of $0.2 \mu \mathrm{M}$ $\left[\mathrm{Ca}^{2+}\right]_{\mathrm{i}}$ and $100 \mu \mathrm{M}$ cAMP. In a series of five experiments, $92 \pm 6 \%$ of the release events detected by amperometry associated with simultaneous ATP release. ATP-dependent TICs not associated with 5-HT release represent events occurring too far away from the carbon fiber to be detected. We compared the half-widths of the amperometric events (excluding events with rise times of $>10 \mathrm{~ms}$ that likely occurred far away from the carbon fiber) with the halfwidths of the TICs. Figure $3 \mathrm{~b}$ shows a TIC superimposed on the corresponding simultaneous amperometric event. The half-widths of events detected by both methods for ${ }^{3} \sqrt{q}$ values of $\leq 25 \mathrm{fC}^{1 / 3}(\leq 15.6 \mathrm{pC})$. 
Fig. 2 a Distribution of ${ }^{3} \sqrt{q}$ obtained in cells dialyzed with $0.2 \mu \mathrm{M}\left[\mathrm{Ca}^{2+}\right]_{\mathrm{i}}$. The red curve is a Gaussian fit to the distribution of $\sqrt[3]{\mathrm{q}}$ values. The TICs in the insert above the histogram are five examples of smallest events observed (i.e., within the first bin). The numbers above the selected events represent the baseline RMS noise level (in pA) for each trace. b Rise times displayed against ${ }^{3} \sqrt{\mathrm{q}}$. Data are presented as mean values \pm SEM for the events within the same bins as used in a. The line was obtained by least-squares analysis of the original data (rise time $\left.=4.9+0.02 \times \sqrt[3]{ } \mathrm{q}: r^{2}=0.11\right)$



b

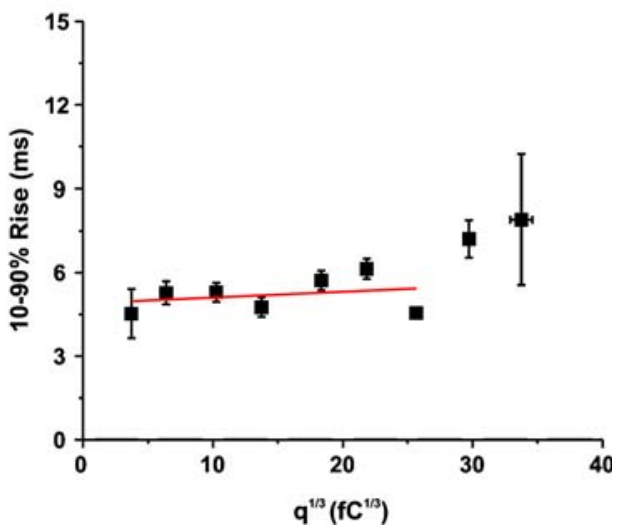

averaged $15 \pm 1$ and $20 \pm 0.5 \mathrm{~ms}(n=93)$ for the amperometric and TIC events, respectively.

Figure $3 \mathrm{c}$ shows the distribution of ${ }^{3} \sqrt{q}$ values for all TICs (gray) and the subset of events $(56 \%$ in this experiment) that were associated with simultaneous 5-HT release (red). The amplitude of both types of events exhibited close to normal distribution. Whereas it can be seen that $>70 \%$ of the ATP-dependent TICs are associated with detectable corelease of 5-HT for ${ }^{3} \sqrt{q}$ values $>20 \mathrm{fC}^{1 / 3}$, the correlation is weaker for smaller events $\left(28 \%\right.$ for ${ }^{3} \sqrt{q}$ values $<8 \mathrm{fC}^{1 / 3}$ ). However, when the effects of amplitude and diffusional loss of 5-HT were taken into account (stippled bars; see "Materials and methods"), the distributions of TICs with and without simultaneous 5-HT release became more similar. Thus, both the location and amplitude of the release events influence the detection of the amperometric events.

Correlation between ATP release and exocytosis detected by capacitance measurements

Exocytosis in $\beta$-cells is normally triggered by $\mathrm{Ca}^{2+}$ entry during glucose-induced action potentials. Because of the strongly inwardly rectifying properties of the $\mathrm{P} 2 \mathrm{X}_{2} \mathrm{Rs}$ [24], the TICs become small and difficult to resolve during membrane depolarization. The time course of $\mathrm{Ca}^{2+}$-induced exocytosis and ATP release was therefore instead determined by photoliberation of caged $\mathrm{Ca}^{2+}\left(\mathrm{Ca}^{2+}-\mathrm{NP}-\right.$ EGTA). Using this approach, exocytosis can proceed even when the membrane potential is held constant at $-70 \mathrm{mV}$ (Fig. 4a). In a series of 37 experiments carried out on 22 cells, in which $\left[\mathrm{Ca}^{2+}\right]_{\mathrm{i}}$ rose to $5.3 \pm 0.5 \mu \mathrm{M}$, the first TIC spike started on average $43 \pm 7 \mathrm{~ms}(n=37)$ after the flash. This is only slightly longer than delay between photo release of $\mathrm{Ca}^{2+}$ and a detectable increase in membrane capacitance which averaged $31 \pm 3 \mathrm{~ms}(n=9)$ in $\beta$-cells not infected with $\mathrm{P} 2 \mathrm{X}_{2}$ Rs. Noninfected $\beta$-cells were used for the latter measurement as time course of the capacitance increase cannot be reliably determined in infected cells because of the large increase in membrane conductance resulting from activation of the $\mathrm{P} 2 \mathrm{X}_{2} \mathrm{Rs}$ that leaks through to the capacitance signal. Figure $4 \mathrm{~b}$ shows examples of TICs upon photoliberation in another four $\beta$-cells. Typically, a step increase in $\left[\mathrm{Ca}^{2+}\right]_{i}$ elicited an initial large TIC spike followed by a series of smaller events. In some cases, individual events were superimposed on the large spike.

ATP release correlated with an increase in membrane capacitance $\left(\Delta C_{\mathrm{m}}\right)$. The increase in membrane capacitance was measured once the membrane current had decayed by $>95 \%$ and the capacitance signal was stable and averaged $105 \pm 13 \mathrm{fF}(n=22)$. The total integrated TIC $(\Sigma Q)$ measured over the same period $(545 \pm 49 \mathrm{~ms})$ and in the same experiments averaged $139 \pm 19 \mathrm{pC}$. When multiple experiments were done on the same cell, the mean values of $\Delta C_{\mathrm{m}}$ and $\Sigma Q$ obtained were used for this analysis.

Figure 4c summarizes the relationship between $Q$ and $\Delta C_{\mathrm{m}}$ in 37 experiments. It can be seen that the $Q$ is linearly related to $\Delta C_{\mathrm{m}}(r=0.8 ; P<0.001)$. The relationship has a slope of $1.2 \pm 0.2 \mathrm{pC} / \mathrm{fF}$.

Spontaneous TICs were sometimes observed before photo releasing $\mathrm{Ca}^{2+}$. The distribution of ${ }^{3} \sqrt{\mathrm{q}}$ values of such events is shown in Fig. 4d. The distribution can be described by a single Gaussian. The mean charge $(\bar{q})$ of these events was $4.2 \pm 0.4 \mathrm{pC}$. Combining this value with the slope of $1.2 \mathrm{pC} / \mathrm{fF}$ suggests a unitary capacitance increase of $3.5 \mathrm{fF}$. This is within $21 \%$ of that observed for LDCV exocytosis in on-cell capacitance measurements (2.9 fF; [7]).

\section{Modeling of ATP release}

We attribute the initial large spike observed following photo release of $\mathrm{Ca}^{2+}$ to the rapid release of many vesicles and 
a

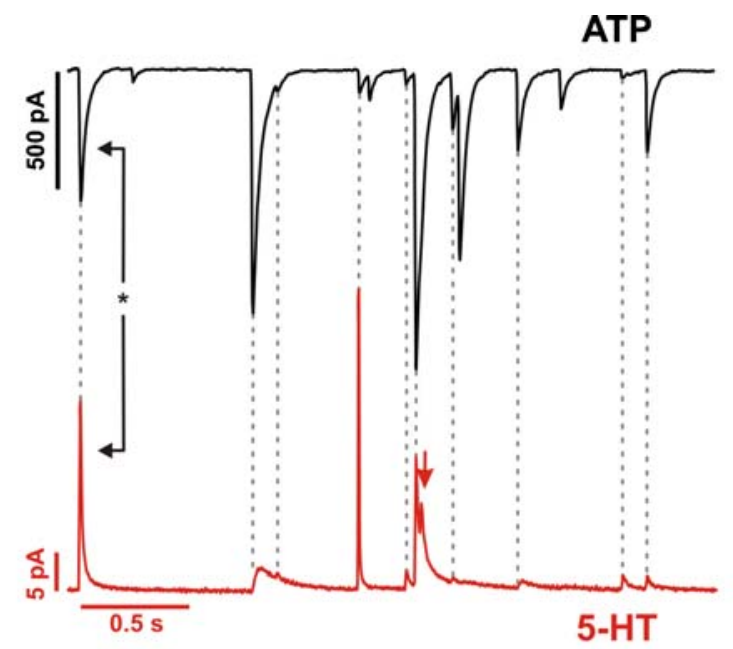

b

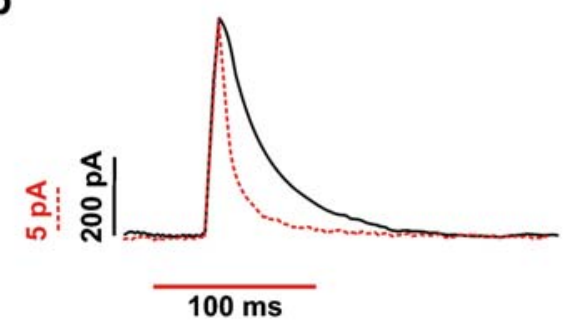

C

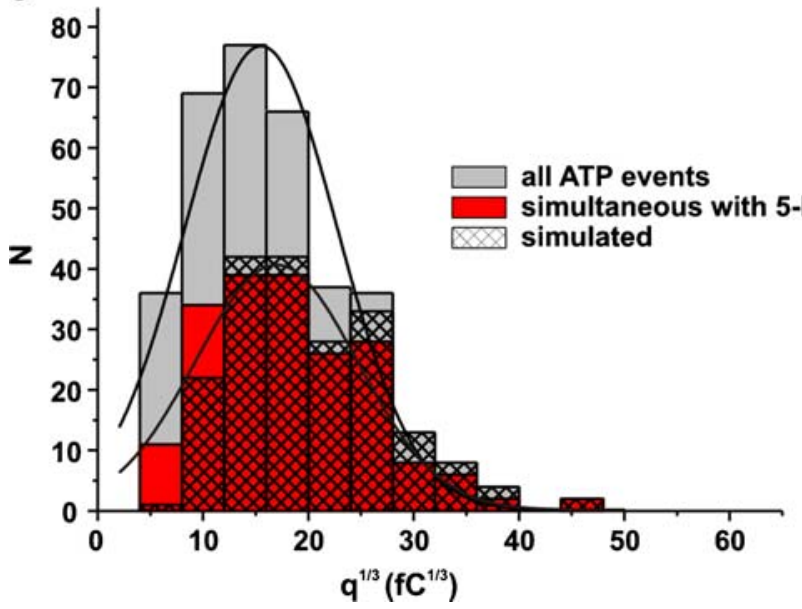

Fig. $3 \mathrm{P}_{2} \mathrm{X}_{2} \mathrm{R}$ currents associated with serotonin release. a Examples of amperometric events (red) with parallel recordings of TICs (black). Red lines indicate simultaneous events. A single amperometric event not associated with a detectable TICs has been highlighted by the arrow. b Comparison of time courses of the amperometric response (red) with the TIC (black) of the event indicated by the asterisk in a. The TIC has been inverted and the responses are scaled to the same amplitude. c Distribution of ${ }^{3} \sqrt{q}$ of all events (gray) and the events associated with serotonin release (red) when exocytosis was evoked by $0.2 \mu \mathrm{M}\left[\mathrm{Ca}^{2+}\right]_{\mathrm{i}}$ and $100 \mu \mathrm{M}$ cAMP. The stippled bars represent the distribution obtained from the original one (gray bars) when allowance is made for the diffusion of ATP and assuming detection of the ATP-dependent TICs by an amperometric sensor (cf. [12]). Gausians have been superimposed on the original distribution (all events, gray) and those that coincided with simultaneous 5-HT release (red) superimposition of the associated TICs. We evaluated this by mathematical modeling. Figure 5 a shows the capacitance change evoked in a representative $\beta$-cell following photo release of caged $\mathrm{Ca}^{2+}$. In this cell, a capacitance increase of $130 \mathrm{fF}$ took place within the first $0.2 \mathrm{~s}$ after the flash of UV light. This corresponds to the release of $45 \mathrm{LDCVs}$ with a unitary capacitance increase of $2.9 \mathrm{fF}$. Exocytosis just after the flash is so rapid that the modeled events merge into what appears as a single large transient and that individual events superimposed on the large spike only become discernible when the current starts returning towards the baseline (compare Fig. 4b). Figure 5b compares the time courses of the capacitance increase (red trace) and the cumulative $Q$ of the simulated response in Fig. 5a (black trace). The increase in membrane capacitance and cumulative $Q$ were half-maximal after 55 and $152 \mathrm{~ms}$, respectively.

In Fig. 5c, the average changes in membrane capacitance $\left(\Delta C_{\mathrm{m}}\right)$ observed in a series of nine cells not expressing P $2 X_{2}$ Rs following a step elevation of $\left[\mathrm{Ca}^{2+}\right]_{i}$ are shown (red trace). It is evident that there is a prompt increase in membrane capacitance of $170 \pm 23 \mathrm{fF}$, that the signal stabilizes at a new plateau within $\sim 2 \mathrm{~s}$, and that there is no sign of ongoing exocytosis or endocytosis during the following $8 \mathrm{~s}$. We compared the time courses of the increase in membrane capacitance with that of ATP released as reported by the TIC measurements. The black trace in Fig. 5d shows the integrated average charge $(\Sigma Q)$ over the first $10 \mathrm{~s}$ after photoliberation of $\mathrm{Ca}^{2+}$ in the five cells shown in Fig. $4 \mathrm{a}$, b. It can be seen that both $\Delta C_{\mathrm{m}}$ and $\Sigma Q$ plateau within $\sim 2 \mathrm{~s}$ and then remained stable. Figure $5 \mathrm{~d}$ shows the responses evoked by the flash on an expanded time base. Whereas $\Sigma Q$ (reflecting ATP release) was halfmaximal after $347 \pm 168 \mathrm{~ms}(n=5)$, the corresponding value was $59 \pm 5 \mathrm{~ms}(n=9)$ for $\Delta C_{\mathrm{m}}$.

Parallel measurements of exocytosis using amperometry, $\mathrm{P} 2 \mathrm{X}_{2} \mathrm{Rs}$, and capacitance measurements

We examined the correlation between the capacitance increase and the release of ATP and the LDCV marker 5HT. Figure 6 a shows an example where elevation of $\left[\mathrm{Ca}^{2+}\right]_{\mathrm{i}}$ to $\sim 10 \mu \mathrm{M}$ evoked a large capacitance increase $(\sim 700 \mathrm{fF})$, a prominent and protracted amperometric response, and a series of TICs with a total charge of $416 \mathrm{pC}$. The responses in this cell are atypically large; the average capacitance increase and integrated TIC evoked by photoliberation of $\mathrm{Ca}^{2+}$ in this series of experiments averaged $204 \pm 72 \mathrm{fF}$ and $239 \pm 57 \mathrm{pC}(n=8)$, respectively. Figure $6 \mathrm{~b}$ shows parallel amperometric and TIC recordings of the same type in another three cells. Figure $6 \mathrm{c}$ compares the time courses of the compound (resulting from the simultaneous fusion of many events) amperometric and TIC response. Consistent 

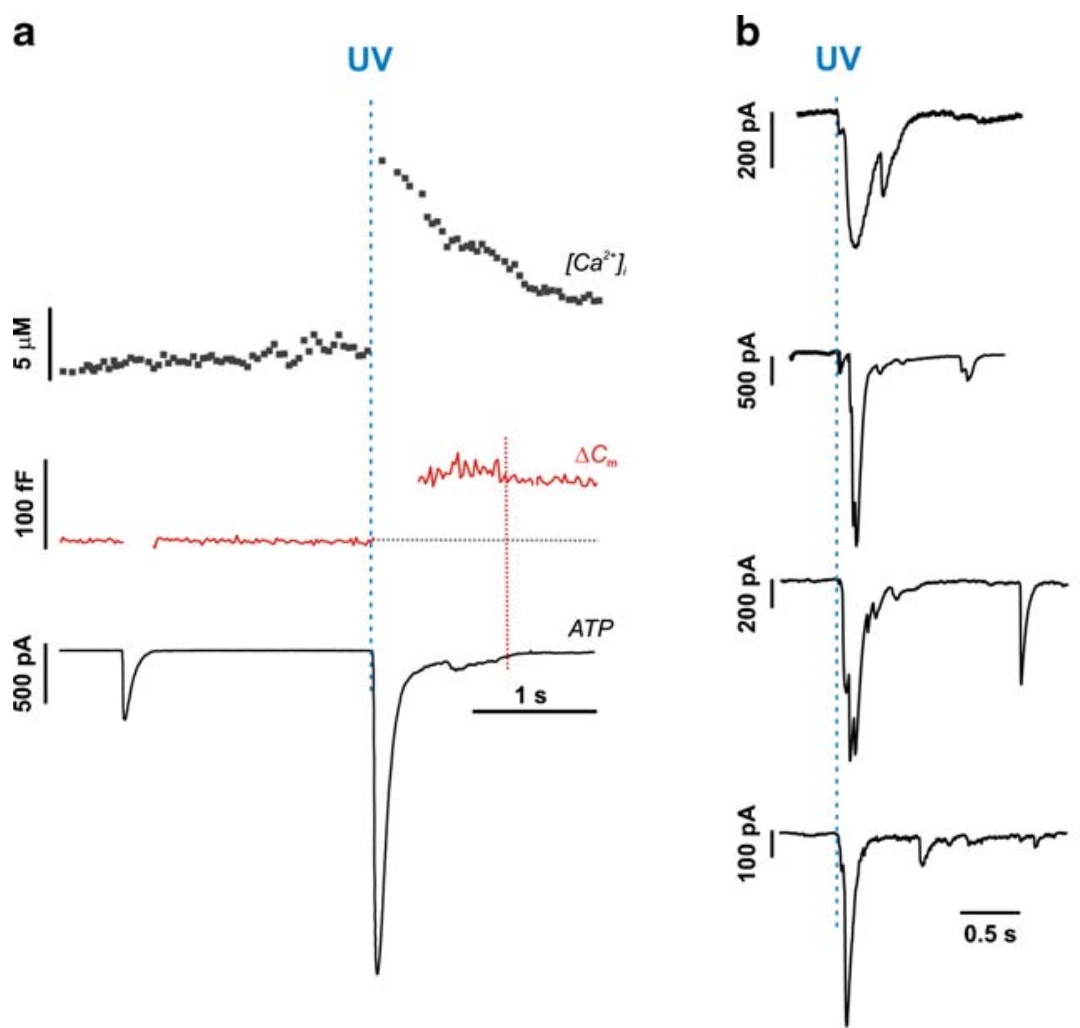

C
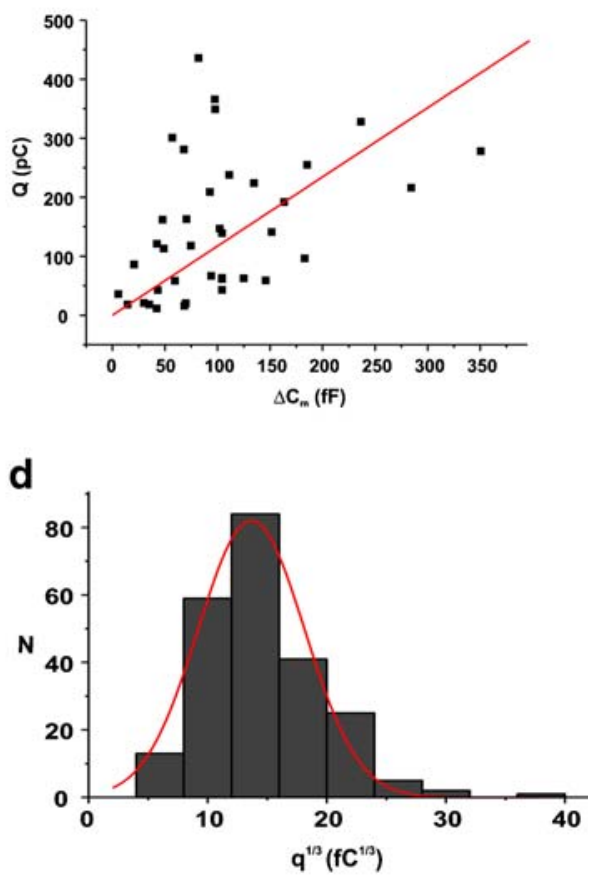

Fig. $4 \mathrm{P} 2 \mathrm{X}_{2}$ receptor currents and changes in $\beta$-cell membrane capacitance evoked by photo release of caged $\mathrm{Ca}^{2+}$. a Increase in $\left[\mathrm{Ca}^{2+}\right]_{\mathrm{i}}($ top $)$, change in membrane capacitance (middle), and associated $\mathrm{P} 2 \mathrm{X}_{2} \mathrm{R}$ current (bottom) transients recorded from a rat $\beta$-cell. The capacitance measurements are not shown during the period associated with the TIC to remove large artifactual transients. b Examples of TIC responses following photo release of $\mathrm{Ca}^{2+}$ in another four cells. $\mathbf{c}$

with the data of Fig. 3b, the TIC develops with the same time course as the amperometric response but the duration of the event is longer.

We point out that UV irradiation of the carbon fiber gives rise to a current artifact that had to be removed digitally off-line. Figure $6 \mathrm{~d}$ illustrates the validity of this procedure. Here, the artifactual response obtained when the cell was removed from the carbon fiber is shown together with the exponential used for subtraction. The lower trace shows the near-complete removal of the artifact.

In Fig. 6e, the average time courses of 5-HT and ATP release are compared in the four cells shown in Fig. 6a, b. In these cells, the integrated amperometric response and TIC were half-maximal at $139 \pm 125$ and $289 \pm 129 \mathrm{~ms}$ $(n=4)$, respectively.

\section{Discussion}

Here, we have used adenoviral infection of rat pancreatic $\beta$ cells to induce expression of a high density of ATPsensitive $\mathrm{P} 2 \mathrm{X}_{2} \mathrm{Rs}$ in the plasma membrane to measure ATP

Relationship between capacitance increase $(\Delta \mathrm{Cm})$ and total TIC charge (Q) evoked by photo release of caged $\mathrm{Ca}^{2+}$. A straight line was fitted to the data points with a slope of $1.2 \pm 0.2 \mathrm{pC} / \mathrm{fF}(r=0.8: P<$ $0.001)$. The charge and capacitance was measured over the period indicated by the dashed vertical line in a. d Distribution of spontaneous events observed prior to photo release of $\left[\mathrm{Ca}^{2+}\right]_{\mathrm{i}}$. A Gaussian has been superimposed

release. Our technique is related to the "sniffer cell" approach, also based on $\mathrm{P}_{2} \mathrm{X}_{2}$ receptors, used previously by Hazama et al. [28] with the difference that the $\beta$-cell releasing ATP is used as its own "sniffer" cell. An advantage of this method over amperometry is that exocytosis can be monitored in the entire cell whereas amperometry only detects secretion in the $30-50 \%$ of the area adjacent to the carbon fiber [23]. We have used this protocol to address two important questions in $\beta$-cell exocytosis. First, is ATP exclusively released by exocytosis of LDCVs? Second, how much of the depolarizationevoked exocytotic responses reported by capacitance measurements reflect fusion of LDCVs?

ATP is released by exocytosis of vesicles that also accumulate 5-HT

Fluorescence microscopy, autoradiography, electron microscopy, and ultrastructural histochemistry indicate that 5-HT accumulates in insulin-containing secretory vesicles of the $\beta$-cell during preloading [29-31]. The validity of amperometry to study exocytosis of insulin-containing 
a

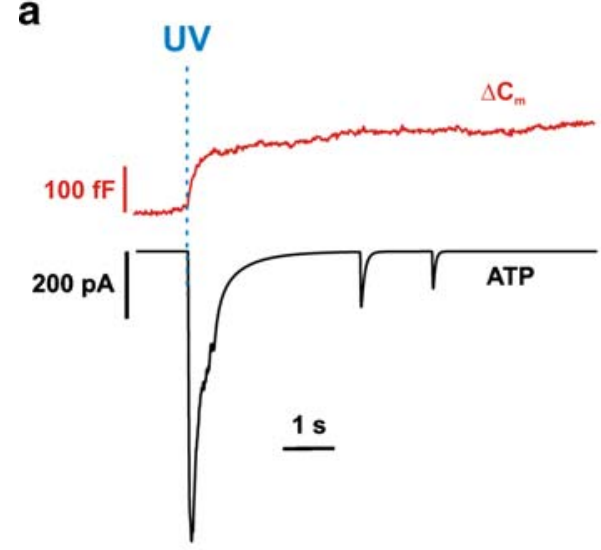

C

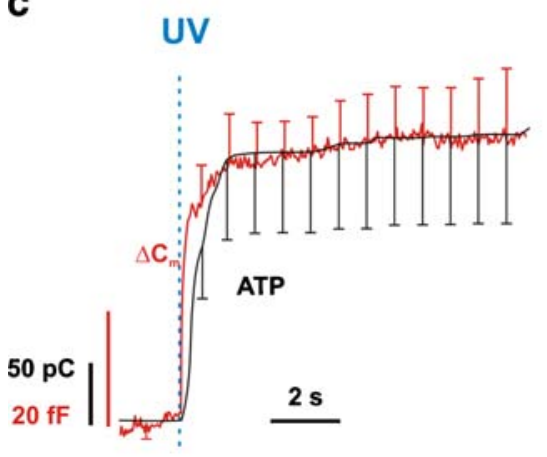

b


Fig. 5 Time course of ATP release and association with capacitance increase. a Predicted time course of ATP release (black trace) following photo release of caged $\mathrm{Ca}^{2+}$ based on a capacitance increase of $130 \mathrm{fF}$ with a $t_{1 / 2}$ of $55 \mathrm{~ms}$ (red trace). b Comparison of time courses of capacitance increase (red trace) and cumulative TIC charge for modeled ATP trace in panel a. c Cumulative charge of TICs of the

granules has been demonstrated [8]. Even if 5-HT accumulated in the SVs, the currents that would result from exocytosis of SVs loaded with the amine would be expected to be very small given the small volume of these vesicles $(2 \%$ of that of an insulin granule as predicted from the diameters of 90 and $330 \mathrm{~nm}$; [6]). There is a good correlation between 5 -HT and ATP release and $92 \%$ of the events detected by amperometry were paralleled by a TIC. The fact that not all amperometric events are associated with ATP release can be explained by uneven loading of the vesicles with ATP and/or insufficient expansion of the fusion pore to allow the exit of ATP which is bigger than 5HT. The latter possibility is suggested by analysis of the pedestals that sometimes precede full fusion and that are believed to reflect release via fusion pore. Although pedestals are observed in both amperometry and TIC recordings, their relative amplitude is much smaller during the latter type of measurements [23].

The parallel recordings of ATP and 5-HT release suggested the existence of a population of small TICs that did not associate with detectable corelease of serotonin five cells shown in Fig. 4a, b (black) superimposed on the mean capacitance increase in untransfected cells $($ red $)$. For clarity, error bars (SEM) are only shown for every 20 (capacitance) and 3,500 (charge) points. d Same data as in $\mathbf{c}$ but the first $2 \mathrm{~s}$ is shown on an expanded time base

(Fig. 3). It may be argued that these events reflect exocytosis of SVs that do not accumulate 5-HT. However, we do not think this is the case but rather a consequence of the lower resolution of amperometry: some events associated with the release of 5-HT will not be detected by the carbon fiber because they are too small and/or occur too far away from the carbon fiber. Indeed, when the distribution was corrected for the greater sensitivity of the $\mathrm{P} 2 \mathrm{X}_{2} \mathrm{R}$-based technique and diffusional loss of 5-HT, a better agreement of the distributions was obtained. Collectively, these data argue that ATP and 5-HT are released by exocytosis of the same type of vesicles and that these are the insulincontaining LDCVs. It therefore appears that ATP should represent a good endogenous marker of insulin granule exocytosis that, unlike 5-HT, does not have to be preloaded into the cells. TIC measurements also have the advantage that they allow the time course of ATP release elicited by photo release of caged $\mathrm{Ca}^{2+}$ without subtraction of the current artifact that results from UV irradiation (see Fig. 6d). However, this is at the price of not being able to correlate ATP release with the time course of vesicle fusion 

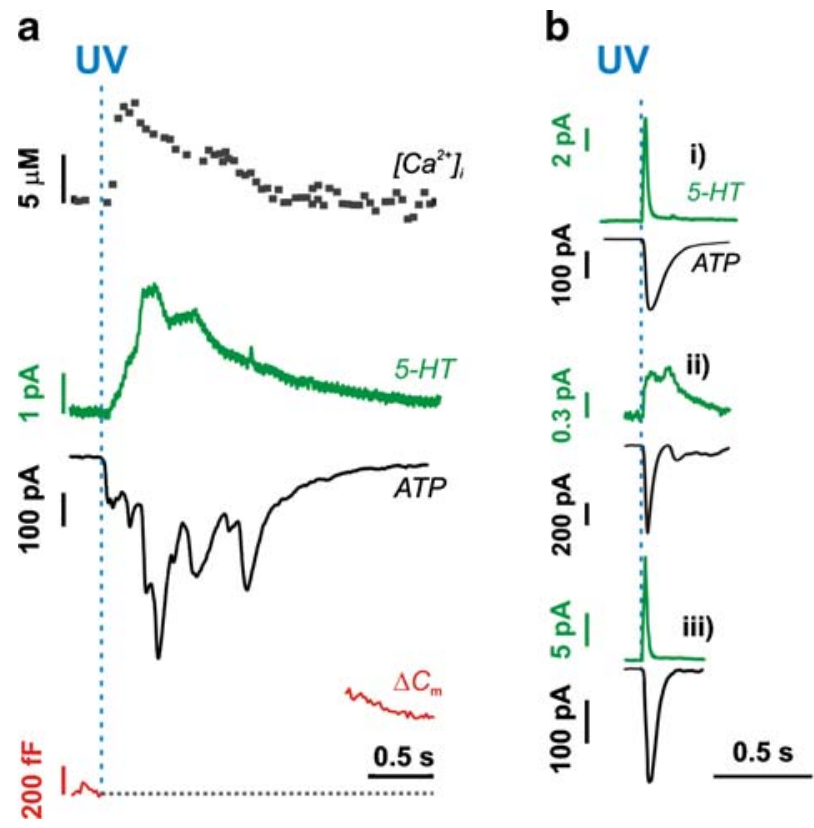

C

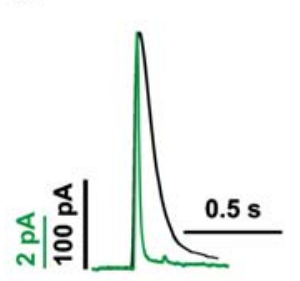

d
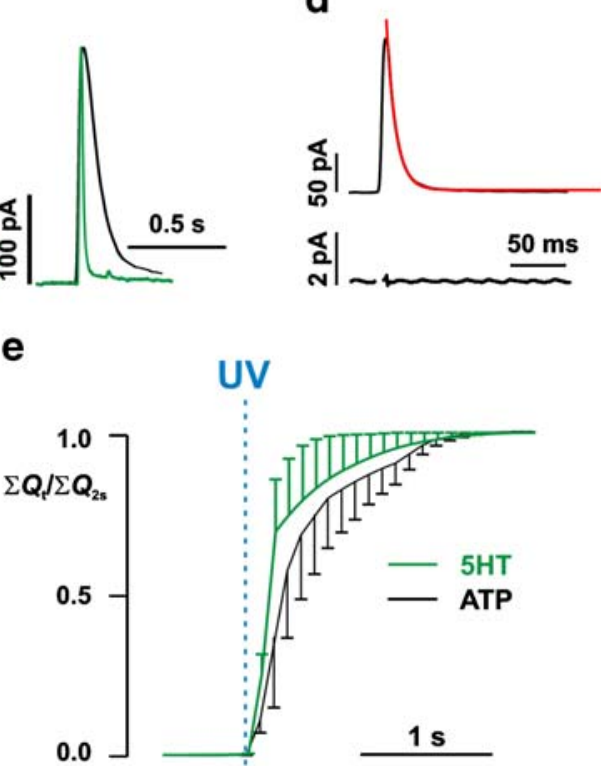

Fig. $6 \mathrm{Ca}^{2+}$-evoked exocytosis monitored by 5-HT amperometry, ATP release, and capacitance measurements. a Increase in $\left[\mathrm{Ca}^{2+}\right]_{\mathrm{i}}$ (top), amperometric transients (second from top), associated TICs (third from top), and change in membrane capacitance (bottom) recorded from a rat $\beta$-cell following photo release of caged $\mathrm{Ca}^{2+}$ by a flash of UV light (dashed vertical line). Note that the capacitance measurements are not shown during the TICs to remove artifactual capacitance transients. b Similar type of recordings from another three cells is shown $(i-i i i)$. Only amperometric and TIC measurements are shown for clarity. c Amperometric response (green) and TIC (black) of cell 1 in panel $\mathbf{b}$. The TIC has been inverted; the responses have been scaled to the same amplitude and are shown on an expanded time

as documented by changes in membrane capacitance as the large conductance changes associated with the activation of the $\mathrm{P} 2 \mathrm{X}_{2} \mathrm{Rs}$ contaminate the capacitance signal.

Sensitivity of the $\mathrm{P} 2 \mathrm{X}_{2} \mathrm{R}$-based method for detection of exocytosis

The smallest TICs we resolved had a peak amplitude as small as $3.2 \mathrm{pA}$. Under the conditions used in these experiments, the $\mathrm{P} 2 \mathrm{X}_{2} \mathrm{R}$ single-channel amplitude is $\sim 1 \mathrm{pA}$ [24]. Thus, the smallest events involve the activation of only a few $\mathrm{P} 2 \mathrm{X}_{2} \mathrm{Rs}$. It is of interest that the rise times for the smallest events are as short as for larger events (Fig. 2b). This argues that they reflect local release of ATP and rapid opening of $\mathrm{P} 2 \mathrm{X}_{2}$ Rs and that their activation does not involve diffusion over long distances. The smallest event observed had a charge of $33 \mathrm{fC}, 0.7 \%$ of the mean charge $(4.3 \mathrm{pC})$. Pancreatic $\beta$-cells contain 4 fmol of ATP per cell [22] of which $30 \%$ is stored in the $\sim 10,000$ insulincontaining secretory granules [14]. Thus, the ATP content per granule is $0.12 \mathrm{amol}\left(1.2 \times 10^{-19} \mathrm{~mol}\right)$. Combining these values suggest that our technique can detect the release of $0.85 \times 10^{-21} \mathrm{~mol}$ of ATP $(\sim 500$ molecules $)$. This would base. $\mathbf{d}$ Current artifacts produced by UV irradiation (black trace) with exponential used for subtraction (red trace superimposed). The resulting current after subtraction of the artifact. Note use of different ordinate scales and that no attempt was made to compensate for the rising phase of the artifact. The initial $\sim 5 \mathrm{~ms}$ has been omitted. This is justifiable since capacitance measurements indicated that there was a delay of $\sim 40 \mathrm{~ms}$ between the flash and the onset of exocytosis. e Average normalized integrated amperometric (green) and TIC charge (black) of the four experiments shown in a, b. Responses have been normalized to the charge recorded during the first $2 \mathrm{~s}$. For clarity, error bars (SEM) are only shown for every 500 points

correspond to an intravesicular concentration of $0.2 \mathrm{mM}$ in an SV with a diameter of $90 \mathrm{~nm}$ and a volume of $0.4 \mathrm{al}$. This is several orders of magnitude lower than the estimated ATP concentration in classical synaptic vesicles [17]. This argues that our technique should have sufficient sensitivity to detect any SV-mediated ATP release in $\beta$-cells.

Do SVs contribute to the observed capacitance increases?

If the total number of SVs and LDCVs undergoing exocytosis is equivalent to $a$ and $b$, respectively, the total charge $(Q)$ of the ATP-evoked current and increase in membrane capacitance $\left(\Delta C_{\mathrm{m}}\right)$ are given by the equations

$\left\{\begin{array}{c}\Delta C_{\mathrm{m}}=c_{\mathrm{m}, \mathrm{SV}} \times a+c_{\mathrm{m}, \mathrm{LDCV}} \times b \\ Q=q_{\mathrm{SV}} \times a+q_{\mathrm{LDCV}} \times b\end{array}\right.$

Single-vesicle capacitance increases for SVs $\left(c_{\mathrm{m}, \mathrm{sv}}\right)$ and LDCVs $\left(c_{\mathrm{m}, \text { LDCV }}\right)$ average 0.2 and $2.9 \mathrm{fF}$, respectively [7]. Whereas the unitary charge of the current associated with the ATP release during exocytosis of an LDCV $\left(q_{\mathrm{LDCV}}\right)$ is $\sim 4.3 \mathrm{pC}$ (Figs. 2a and 4a), the unitary charge evoked by 
ATP release due to exocytosis of SVs $\left(q_{\mathrm{SV}}\right)$ is not known. We therefore consider three possibilities: (1) SVs contain no ATP at all (i.e., $q_{\mathrm{sv}}=0$ ); (2) SVs contain ATP at the same concentration as the LDCVs but, because the volume of an SV is only $2 \%$ of the LDCVs, the amount of ATP released during SV exocytosis will be correspondingly reduced (i.e., $q_{\mathrm{SV}}=0.02 \times q_{\mathrm{LDCV}}$ ); and (3) SVs contain ATP at a $\sim 50$-fold higher concentration than the LDCVs so that exactly the same amount of ATP is delivered during exocytosis of SVs and LDCVs $\left(q_{\mathrm{SLMV}}=q_{\mathrm{LDCV}}\right)$. We point out that cases (1) and (3) are consistent with the single peak in the amplitude distribution (Fig. 2a) and the rise times being constant for a wide range of TIC amplitudes (cf. [32]). However, case (2) is not supported by the experimental data. If SVs contained ATP at the same concentration as the LDCVs and if they are released at a rate comparable to that of the LDCVs as suggested by on-cell capacitance measurements [7], then a second peak should appear at $3.6-4.5 \mathrm{fC}^{1 / 3}$ in the histogram shown in Fig. 2a. However, no such peak was observed. Likewise, the analysis of the rise times provided no evidence for two distinct release pathways characterized by different time courses for ATP release as would be expected for vesicles with widely different diameters [32].

With the experimentally observed values of $\Delta C_{\mathrm{m}}$ and $Q$ $(105 \mathrm{fF}$ and $139 \mathrm{pC})$, solving Eqs. 1 and 2 yields values for $b$ and $a$ of 32 and 56 for case $1\left(q_{\mathrm{SV}}=0\right), 30$ and 87 for case $2\left(q_{\mathrm{SV}}=0.02 \times \mathrm{q}_{\mathrm{LDCV}}\right)$, and 36 and 0 for case $3\left(q_{\mathrm{SV}}=\right.$ $\left.q_{\text {LDCV }}\right)$. These values indicate that exocytosis of LDCV accounts for $>95 \%$ of the ATP release and $>85 \%$ of the observed capacitance increases. The conclusion that the capacitance changes and TICs principally reflect exocytosis of LDCVs is also consistent with the previous finding that the capacitance increase per TIC is $\sim 3 \mathrm{fF}$ [21]. The fact that a similar capacitance increase per event ( $3.5 \mathrm{fF}$; Fig. $4 \mathrm{c}$ ) can be estimated from the relationship between charge and capacitance increase in the experiments involving photo release of caged $\mathrm{Ca}^{2+}$ provides further support of this idea. We acknowledge that this analysis rests on the assumption that the spontaneous miniature events have the same $q$ as those that are triggered by uncaging of $\mathrm{Ca}^{2+}$. The validity of the assumption is supported by the finding that the amplitude distribution of the TICs in excised outside patches at $2 \mu \mathrm{M}\left[\mathrm{Ca}^{2+}\right]_{\mathrm{i}}$ is the same as that seen in whole-cell recordings at $0.2 \mu \mathrm{M}\left[\mathrm{Ca}^{2+}\right]_{\mathrm{i}}$ (Hoppa et al., submitted manuscript).

The above analysis depends critically on the accuracy of the capacitance measurements. Changes in cell capacitance reflect the balance between the insertion of membrane during exocytosis and its recapture by endocytosis. Endocytosis is triggered with a delay after exocytosis and operates at much lower rate than exocytosis [33]. Several precautions were taken to minimize potential confounding effects of endocytosis. First, $\Delta C_{\mathrm{m}}$ was measured as soon as the TICs had returned to the baseline. Second, we used moderate stimulus (peak $\left[\mathrm{Ca}^{2+}\right]_{\mathrm{i}} \sim 5 \mu \mathrm{M}$; compare [34]). Indeed, the capacitance measurements showed little sign of endocytosis and $\Delta C_{\mathrm{m}}$ attained a new and stable plateau within $\sim 1 \mathrm{~s}$ where it subsequently remained for at least $9 \mathrm{~s}$. The integrated TIC charge likewise increased to a plateau within $1 \mathrm{~s}$ and there was no sign of ongoing exocytosis during the subsequent $9 \mathrm{~s}$. These observations suggest that $\Delta C_{\mathrm{m}}$ is not masked by ongoing endocytosis and that we accordingly do not underestimate the true extent of exocytosis. In this context, it may also be relevant that endocytosis is poorly preserved during standard whole-cell recordings $[33,35]$.

Temporal dissociation between capacitance increase and ATP release

Interestingly, there was a 300 -ms delay between $\Delta C_{\mathrm{m}}$ and $\Sigma Q$ (Fig. 5b). There is a simple explanation to this delay. Whereas the capacitance increase occurs almost instantaneously upon exocytosis, the $\mathrm{P} 2 \mathrm{X}_{2} \mathrm{R}$ currents activate with some delay ( $\sim 5 \mathrm{~ms}$; Fig. 2b) upon exposure to ATP and then decay exponentially as the agonist diffuses away from the release site. Thus, $\Sigma Q$ will plateau once the channels have deactivated and this may, depending on the amplitude and time course of the exocytotic response, take several hundred milliseconds (see Fig. 5d). Thus, it is only natural that the integrated current lags behind $\Delta C_{\mathrm{m}}$ and the dissociation is therefore not indicative of the exocytosis of vesicles containing or lacking ATP. A similar argument can be construed to explain why the integrated TIC lags somewhat behind the amperometric response.

\section{Comparison with previous work}

We acknowledge that the low rate of SV exocytosis suggested by our analysis contrasts with data obtained by two-photon extracellular polar-tracer image quantification which suggest release rates as high as 4,000 SVs $(20 \%$ increase in FM1-43 fluorescence in 0.3 s) [36], i.e., 45fold higher than the rate we observe (maximally $87 \mathrm{SVs}$ over $\sim 550 \mathrm{~ms}$ as in case 2 above). The functional significance of SV exocytosis is unclear. Although it was originally believed that they could mediate gamma-aminobutyric acid (GABA) release [5], more recent analysis suggests that most exocytotic release of GABA principally occurs during release of the insulin granules [23]. The present data also appear to exclude a role of the SVs in ATP release. The identity of the compound released during SV exocytosis (if any) therefore remains to be determined. It is even possible that $\mathrm{SV}$ exocytosis does not at all subserve a function in the export of molecules into the islet interstitium. Instead, rapid exocytosis and endocytosis of SV may 
provide the $\beta$-cell with a means of dynamic regulation of the cell's surface area or a mechanism for insertion of essential transmembrane proteins into the plasma membrane. Yet another possibility is that it is part of a membrane repair reaction [37]. Further work combining measurements of exocytosis by capacitance and TIC measurements with optical imaging of exocytosis are likely to be helpful in the exploration of these questions.

\section{Materials and methods}

\section{Adenovirus construction}

AdP2 $\mathrm{X}_{2} \mathrm{R}$-GFP was created using Adeno- $\mathrm{X}^{\mathrm{TM}}$ Expression system (BD Biosciences Clontech, Erembodegem, Belgium). In short, cDNA encoding the rat $\mathrm{P} 2 \mathrm{X}_{2} \mathrm{R}$ linked to GFP (kindly provided by B.S. Khakh, Cambridge, UK) was subcloned into a pShuttle vector. The expression cassette was then excised using PI-Sce and I-Ceu I and ligated into pAdeno-X, and the resulting adenoviral DNA was transfected into HEK293 cells for harvesting.

\section{$\beta$-cell preparation and infection}

Pancreatic islets were isolated from Sprague-Dawley or Wistar rats. The animals were sacrificed by $\mathrm{CO}_{2}$ inhalation (slowly increasing the concentration of $\mathrm{CO}_{2}$ ). The pancreas was quickly excised and pancreatic islets were isolated by collagenase digestion. The islets thus obtained were dissociated into single cells by titration in $\mathrm{Ca}^{2+}$ free, and the resulting cell suspension was plated on Petri dishes. The cells were maintained in tissue culture for up to 2 days in RPMI 1640 medium (10 mM glucose; Gibco BRL) supplemented with $10 \%$ fetal calf serum, $100 \mu \mathrm{g} / \mathrm{ml}$ streptomycin, and penicillin (100 i.u. $/ \mathrm{ml})$. The $\beta$-cells were infected with the adenoviral construct of P2 $\mathrm{X}_{2} \mathrm{R}-\mathrm{GFP}$ once they had attached to the bottom of the culture dish. Four to $6 \mathrm{~h}$ after infection, the culture medium was replaced with fresh medium without the virus. The cells were used for experimental analysis $24-36 \mathrm{~h}$ after infection.

\section{Solutions}

During the experiment, the cells were continuously superfused with extracellular solution containing $138 \mathrm{mM} \mathrm{NaCl}$, $5.6 \mathrm{mM} \mathrm{KCl}, 2.6 \mathrm{mM} \mathrm{CaCl}_{2}, 1.2 \mathrm{mM} \mathrm{MgCl}_{2}, 5 \mathrm{mM}$ HEPES, $5 \mathrm{mM}$ D-glucose. The $\mathrm{pH}$ of the medium was adjusted to 7.4 with $\mathrm{NaOH}$. The osmolarity of the medium was $\sim 290 \mathrm{mOsm}$. In the experiments in which exocytosis was triggered by intracellular dialysis, the $0.2 \mu \mathrm{M}\left[\mathrm{Ca}^{2+}\right]_{\mathrm{i}}$ media contained $110 \mathrm{mM}$ Cs-glutamate $(110 \mathrm{mM}$ glutamic acid + $110 \mathrm{mM} \mathrm{CsOH}), 10 \mathrm{mM} \mathrm{KCl}, 10 \mathrm{mM} \mathrm{NaCl}, 1 \mathrm{mM}$
$\mathrm{MgCl}_{2}, 3 \mathrm{mM}$ MgATP, $0.1 \mathrm{mM}$ cAMP, $5 \mathrm{mM}$ HEPES, $5 \mathrm{mM} \mathrm{CaCl}_{2}$, and $10 \mathrm{mM}$ EGTA, whereas the $\sim 2 \mu \mathrm{M}$ $\left[\mathrm{Ca}^{2+}\right]_{\mathrm{i}}$ buffer consisted of $3 \mathrm{mM} \mathrm{MgATP}, 1 \mathrm{mM} \mathrm{MgCl}{ }_{2}$, $0.1 \mathrm{mM}$ cAMP, $10 \mathrm{mM}$ HEPES, $120 \mathrm{mM}$ Cs-glutamate, $10 \mathrm{mM} \mathrm{KCl}, 10 \mathrm{mM} \mathrm{NaCl}, 5 \mathrm{mM}$ HEDTA, and $0.57 \mathrm{mM}$ $\mathrm{CaCl}_{2}$. In all cases, $\mathrm{pH}$ was adjusted to 7.1 using $\mathrm{CsOH}$. The free $\mathrm{Ca}^{2+}$ concentration was estimated using the MAXC32 software (http://www.stanford.edu/ cpatton/ maxc.html).

\section{Electrophysiology}

Patch electrodes (4-7-M $\Omega$ resistance when filled with the pipette solution) were pulled from borosilicate glass capillaries (Hilgenberg, Malsfeld, Germany). The electrodes were coated with Sylgard close to the tips and firepolished. The electrophysiological measurements were made using an EPC-10 patch clamp amplifier and Pulse 8.51 software (Heka Elektronik, Lambrecht/Pfalz, Germany). All experiments were conducted using the standard whole-cell configuration at $\sim+34^{\circ} \mathrm{C}$. The cells were voltage-clamped at $-70 \mathrm{mV}$ to prevent activation of voltage-gated $\mathrm{Ca}^{2+}$ channels. Exocytosis was elicited by $\mathrm{Ca}^{2+}$ infusion through patch electrode or by photo release of caged $\mathrm{Ca}^{2+}$ and the changes of capacitance caused by the fusion of secreted vesicles with the cell membrane was detected using Sine+DC method of the Pulse Lockin module. The measurements were made using an EPC-10 patch clamp amplifier and Pulse 8.51 software (Heka Elektronik, Lambrecht/Pfalz, Germany). The ATP-activated currents were filtered at $3.33 \mathrm{kHz}$ and digitized at $10 \mathrm{kHz}$. When ATP release measurements were combined with recordings of membrane capacitance, the current transients were (for display purposes) filtered at $100 \mathrm{~Hz}$ to remove the current noise that results from the sine wave applied to measure membrane capacitance. ATP was applied using a nanoliter injector (Nanoliter 2000, World Precision Instruments, USA) with a speed of $23 \mathrm{nl} / \mathrm{s}$. The total volume applied was $50.6 \mathrm{nl}$. All experiments were conducted on isolated $\beta$-cells far away from neighbors to ensure that currents measured reflect events in the patch-clamped cell only. In addition, the extracellular medium contained a low (5 $\mathrm{mM}$ ) glucose concentration to prevent spontaneous action potential firing (and exocytosis) in the nonclamped cells. Successfully infected cells were identified by the presence of GFP fluorescence.

\section{Amperometry}

For amperometry, $\beta$-cells were loaded with serotonin by adding $0.5 \mathrm{mM}$ 5-HT and $0.5 \mathrm{mM}$ 5-HTP (both from Sigma, St. Louis, MO, USA) to the cell culture $>4 \mathrm{~h}$ before the experiment. A carbon fiber (tip diameter $5 \mu \mathrm{m}$; ProCFE, 
Dagan Corp., Minneapolis, MN, USA) was connected to the second headstage of an EPC-9/2 amplifier (Heka Elektronik, Lambrecht, Germany) and held at $+650 \mathrm{mV}$; the other headstage was used for the measurements of ATP release and membrane capacitance. The carbon fiber was positioned in the immediate vicinity of the $\beta$-cell. The amperometric currents were filtered at $0.3 \mathrm{kHz}$ and digitized at $1 \mathrm{kHz}$. The events were identified by visual inspection of the recording. Their amplitude typically was less than fourfold higher than the background noise level. UV illumination gave rise to transient current artifacts that we removed digitally off-line by fitting an exponential to the initial part of the current and subtracting it from the current response observed as outlined in Fig. 6d.

Photo release of caged $\mathrm{Ca}^{2+}$ and $\left[\mathrm{Ca}^{2+}\right]_{\mathrm{i}}$ measurements

Photolysis of the $\mathrm{Ca}^{2+}$-NP-EGTA complex was effected by brief ( $\sim 1 \mathrm{~ms})$ flashes of UV light produced by a JML-C2 flash photolysis apparatus (Rapp OptoElectronic, Hamburg, Germany). Photolysis was in most cases effected via the objective with the help of a custom-made spot illumination adaptor (Rapp OptoElectronic) mounted on an Axiovert 200 microscope (Carl Zeiss, Göettingen, Germany). For these experiments, the cells were plated on quartz glass coverslips (UQG Optics, Cambridge, UK) to minimize loss of UV light. The intracellular buffer for flash photolysis experiments contained $110 \mathrm{mM} \mathrm{CsCl}, 10 \mathrm{mM} \mathrm{KCl}, 10 \mathrm{mM}$ $\mathrm{NaCl}, 2 \mathrm{mM} \mathrm{CaCl}_{2}, 1 \mathrm{mM} \mathrm{MgCl}$, $25 \mathrm{mM}$ HEPES, $3 \mathrm{mM}$ MgATP, $0.1 \mathrm{mM}$ cAMP, $3 \mathrm{mM}$ NP-EGTA (o-nitrophenyl EGTA, tetrapotassium salt; Synaptic Systems GmbH, Göettingen, Germany), and $0.05 \mathrm{mM}$ of the fluorescent low-affinity $\mathrm{Ca}^{2+}$ indicator Fura-FF (Invitrogen). The measurements were made using an epifluorescence imaging system (PTI Fluorescent Master Systems, NJ, USA). The excitation and emission wavelengths used for Fura-FF were $340 / 380$ and $>505 \mathrm{~nm}$, respectively. To convert the fluorescence ratio into $\left[\mathrm{Ca}^{2+}\right]_{\mathrm{i}}$, the minimum ratio was determined at basal $\left[\mathrm{Ca}^{2+}\right]_{i}$ for each experiment. The maximum ratio was recorded immediately after rupturing the cell, by briefly clamping the membrane voltage to $+500 \mathrm{mV}$. The $K_{\mathrm{d}}$ for the binding of $\mathrm{Ca}^{2+}$ to Fura-FF was assumed as $5.5 \mu \mathrm{M}$ (http://probes.invitrogen.com/).

\section{Correction of histograms for diffusion of ATP}

The $\mathrm{P} 2 \mathrm{X}_{2}$-receptor-based technique we have used in this study allows detection of exocytosis over the entire cell surface. By contrast, amperometry principally detects exocytosis in the close vicinity to the carbon fiber and both the time course and amplitude of events occurring in other parts of the cell will be distorted by diffusion (Fig. 1a). This complicates the comparison of histograms that include all
ATP-dependent TICs with those that only include events that associated with corelease of 5-HT as detected by amperometry (Fig. 3). Inevitably, small events will be filtered out with a resultant selection bias towards larger events.

The attenuation and delay of amperometric events caused by the diffusion of released molecules to the carbon fiber have previously been analyzed in detail by Haller et al. [12] using Monte Carlo methods. We used the results presented in Table 1 of that study and the original distribution of all ATP-dependent TICs (gray bars in Fig. 3b) to predict the distribution had the events instead been detected by an ATP-sensitive amperometric sensor detecting ATP in only part of the cell. To this end, the observed TICs were randomly assigned to 11 classes of release sites taking into account probabilities for events to happen at these sites (probabilities and classes of events as in [12]). The events were then scaled for the charge lost due to diffusion and their amplitudes corrected according to expected calculated half-widths. In this step, it was assumed that the current transient can be approximated by an exponential with an area below it equal to a product of the spike amplitude and the half-width of the spike. Then, all original events were sorted in descending order according to corrected amplitudes. Finally, the histogram of ATP events that should be detected by the carbon fiber was constructed from the $n$ first sorted events, where $n$ is the number of ATP events that coincide with amperometric transients. The remaining events obviously were of an amplitude below the detection level of the equipment used and were not included in the corrected histogram.

\section{Mathematical simulation of ATP release}

A unitary spike (amplitude $\sim 100$ pA with a rise time of $5 \mathrm{~ms}$ and a half-width of $18 \mathrm{~ms}$ ) was used to simulate the current response elicited by ATP release following photo release of caged $\mathrm{Ca}^{2+}$ and stimulation of exocytosis. Experimentally observed spikes vary in size and kinetics. Therefore, the amplitude and half-width of the spikes were varied between 50-200 pA and 16-22 ms, respectively. Following the UV flash and the stimulation of exocytosis, 45 granules (corresponding to a capacitance increase of $130 \mathrm{fF}$ ) were released at exponentially increasing times with a $t_{1 / 2}$ of $55 \mathrm{~ms}$.

\section{Data analysis and statistical evaluation}

The current transients were analyzed using the Mini Analysis Program 6.0.3 (Synaptosoft, USA) to determine the peak amplitude, charge, and rise time (10-90\% of the amplitude). An event was identified as an excursion from the baseline three times the RMS noise (on average $2 \pm$ $1 \mathrm{pA} ; n=25)$. 
The magnitude of an event (determined as the charge $q$ of the current resulting from an exocytotic event) will depend on the amount of ATP released. The latter parameter is given by the product of the intragranular concentration of ATP and the volume of the granule (i.e., $\left.4 \pi r^{3} / 3\right)$. Electron microscopy has established that the radii of both the SVs and LDCVs are normally distributed [6]. The cubic root of the charge should also be normally distributed and the data are accordingly presented as ${ }^{3} \sqrt{q}$ in Figs. 1, 2, and 3. The ATP concentration within the vesicles is also likely to be normally distributed but the product of two normal distributions (i.e., the ATP content and thus ${ }^{3} \sqrt{q}$ ) remains a normal distribution although the spread (coefficient of variation) will be greater.

Unless otherwise indicated, data are quoted as mean values \pm SEM of the indicated number of experiments. Statistical significances for the observed differences were evaluated by Student's $t$ test.

Acknowledgements We thank Dr Baljit S. Khakh for generously providing the $\mathrm{P} 2 \mathrm{X}_{2}$-GFP construct and financial support was obtained from the Wellcome Trust, the European Union (LSHB-CT-2004005137 and LSHM-CT-2006-518153). PR is a Wolfson-Royal Society Merit Award Research Fellow.

\section{References}

1. Wightman RM, Jankowski JA, Kennedy RT, Kawagoe KT, Schroeder TJ, Leszczyszyn DJ, Near JA, Diliberto EJ Jr, Viveros OH (1991) Temporally resolved catecholamine spikes correspond to single vesicle release from individual chromaffin cells. Proc Natl Acad Sci USA 88:10754-10758

2. Chow RH, Klingauf J, Neher E (1994) Time course of Ca2+ concentration triggering exocytosis in neuroendocrine cells. Proc Natl Acad Sci USA 91:12765-12769

3. Kasai H (1999) Comparative biology of $\mathrm{Ca}^{2+}$-dependent exocytosis: implications of kinetic diversity for secretory function. Trends Neurosci 22:88-93

4. Rorsman P, Renstrom E (2003) Insulin granule dynamics in pancreatic beta cells. Diabetologia 46:1029-1045

5. Reetz A, Solimena M, Matteoli M, Folli F, Takei K, De Camilli P (1991) GABA and pancreatic beta-cells: colocalization of glutamic acid decarboxylase (GAD) and GABA with synaptic-like microvesicles suggests their role in GABA storage and secretion. Embo J 10:1275-1284

6. Braun M, Wendt A, Birnir B, Broman J, Eliasson L, Galvanovskis J, Gromada J, Mulder H, Rorsman P (2004) Regulated exocytosis of GABA-containing synaptic-like microvesicles in pancreatic beta-cells. J Gen Physiol 123:191-204

7. MacDonald PE, Braun M, Galvanovskis J, Rorsman P (2006) Release of small transmitters through kiss-and-run fusion pores in rat pancreatic beta cells. Cell Metab 4:283-290

8. Aspinwall CA, Huang L, Lakey JR, Kennedy RT (1999) Comparison of amperometric methods for detection of exocytosis from single pancreatic beta-cells of different species. Anal Chem 71:5551-5556

9. Smith PA, Duchen MR, Ashcroft FM (1995) A fluorimetric and amperometric study of calcium and secretion in isolated mouse pancreatic beta-cells. Pflugers Arch 430:808-818
10. Bokvist K, Holmqvist M, Gromada J, Rorsman P (2000) Compound exocytosis in voltage-clamped mouse pancreatic beta-cells revealed by carbon fibre amperometry. Pflugers Arch 439:634-645

11. Smith PA, Proks P, Ashcroft FM (1999) Quantal analysis of 5hydroxytryptamine release from mouse pancreatic beta-cells. J Physiol 521(Pt 3):651-664

12. Haller M, Heinemann C, Chow RH, Heidelberger R, Neher E (1998) Comparison of secretory responses as measured by membrane capacitance and by amperometry. Biophys J 74:2100-2113

13. Becherer U, Pasche M, Nofal S, Hof D, Matti U, Rettig J (2007) Quantifying exocytosis by combination of membrane capacitance measurements and total internal reflection fluorescence microscopy in chromaffin cells. PLoS ONE 2:e505

14. Detimary P, Jonas JC, Henquin JC (1996) Stable and diffusible pools of nucleotides in pancreatic islet cells. Endocrinology 137:4671-4676

15. Hutton JC, Penn EJ, Peshavaria M (1983) Low-molecular-weight constituents of isolated insulin-secretory granules. Bivalent cations, adenine nucleotides and inorganic phosphate. Biochem J 210:297-305

16. Leitner JW, Sussman KE, Vatter AE, Schneider FH (1975) Adenine nucleotides in the secretory granule fraction of rat islets. Endocrinology 96:662-677

17. Pankratov Y, Lalo U, Verkhratsky A, North RA (2006) Vesicular release of ATP at central synapses. Pflugers Arch 452:589-597

18. Khakh BS, Bao XR, Labarca C, Lester HA (1999) Neuronal P2X transmitter-gated cation channels change their ion selectivity in seconds. Nat Neurosci 2:322-330

19. MacDonald PE, Obermuller S, Vikman J, Galvanovskis J, Rorsman P, Eliasson L (2005) Regulated exocytosis and kiss-and-run of synaptic-like microvesicles in INS-1 and primary rat beta-cells. Diabetes 54:736-743

20. Obermuller S, Lindqvist A, Karanauskaite J, Galvanovskis J, Rorsman P, Barg S (2005) Selective nucleotide-release from dense-core granules in insulin-secreting cells. J Cell Sci 118:4271-4282

21. Braun M, Wendt A, Karanauskaite J, Galvanovskis J, Clark A, MacDonald PE, Rorsman P (2007) Corelease and differential exit via the fusion pore of GABA, serotonin, and ATP from LDCV in rat pancreatic beta cells. J Gen Physiol 129:221-231

22. Detimary P, Dejonghe S, Ling Z, Pipeleers D, Schuit F, Henquin JC (1998) The changes in adenine nucleotides measured in glucose-stimulated rodent islets occur in beta cells but not in alpha cells and are also observed in human islets. J Biol Chem 273:33905-33908

23. Braun M, Wendt A, Karanauskaite J, Galvanovskis J, Clark A, Macdonald PE, Rorsman P (2007) Corelease and differential exit via the fusion pore of GABA, serotonin, and ATP from LDCV in Rat Pancreatic \{beta\} Cells. J Gen Physiol 129:221-231

24. Ding S, Sachs F (1999) Single channel properties of P2X2 purinoceptors. J Gen Physiol 113:695-720

25. Whitlock A, Burnstock G, Gibb AJ (2001) The single-channel properties of purinergic P2X ATP receptors in outside-out patches from rat hypothalamic paraventricular parvocells. Pflugers Arch 443:115-122

26. Pethig R, Jakubek LM, Sanger RH, Heart E, Corson ED, Smith PJ (2005) Electrokinetic measurements of membrane capacitance and conductance for pancreatic beta-cells. IEE Proc Nanobiotechnol 152:189-193

27. Taschenberger H, Juttner R, Grantyn R (1999) $\mathrm{Ca}^{2+}$-permeable $\mathrm{P} 2 \mathrm{X}$ receptor channels in cultured rat retinal ganglion cells. $\mathrm{J}$ Neurosci 19:3353-3366

28. Hazama A, Hayashi S, Okada Y (1998) Cell surface measurements of ATP release from single pancreatic beta cells using a novel biosensor technique. Pflugers Arch 437:31-35 
29. Ekholm R, Ericson LE, Lundquist I (1971) Monoamines in the pancreatic islets of the mouse. Subcellular localization of 5hydroxytryptamine by electron microscopic autoradiography. Diabetologia 7:339-348

30. Hellman B, Lernmark A, Sehlin J, Taljedal IB (1972) Transport and storage of 5-hydroxytryptamine in pancreatic-cells. Biochem Pharmacol 21:695-706

31. Owman C, Hakanson R, Sundler F (1973) Occurrence and function of amines in endocrine cells producing polypeptide hormones. Fed Proc 32:1785-1791

32. Bruns D, Riedel D, Klingauf J, Jahn R (2000) Quantal release of serotonin. Neuron 28:205-220

33. Eliasson L, Proks P, Ammala C, Ashcroft FM, Bokvist K, Renstrom E, Rorsman P, Smith PA (1996) Endocytosis of secretory granules in mouse pancreatic beta-cells evoked by transient elevation of cytosolic calcium. J Physiol 493(Pt 3): $755-767$

34. Sorensen JB (2004) Formation, stabilisation and fusion of the readily releasable pool of secretory vesicles. Pflugers Arch 448:347-362

35. Smith C, Neher E (1997) Multiple forms of endocytosis in bovine adrenal chromaffin cells. J Cell Biol 139:885-894

36. Hatakeyama H, Takahashi N, Kishimoto T, Nemoto T, Kasai H (2007) Two cAMP-dependent pathways differentially regulate exocytosis of large dense-core and small vesicles in mouse betacells. J Physiol 582:1087-1098

37. Togo T, Alderton JM, Steinhardt RA (2000) The mechanism of cell membrane repair. Zygote 1(8 Suppl):S31-S32 